\title{
MICROSATELLITE INSTABILITY IN SOLITARY AND SPORADIC GASTRIC CANCER
}

\author{
Rodrigo Oliva Perez, Carlos Eduardo Jacob, Fabricio L'ofreddo D'Ottaviano, \\ Conrado Alvarenga, Adriana Safatle Ribeiro, Ulysses Ribeiro Jr., Cláudio José \\ Caldas Bresciani, Bruno Zilberstein, José Eduardo Krieger, Angelita Habr-Gama \\ and Joaquim José Gama-Rodrigues
}

Perez RO et al. Microsatellite instability in solitary and sporadic gastric cancer. Rev. Hosp. Clín. Fac. Med. S. Paulo 59(5):279-285, 2004.

Recently, the presence of microsatellite instability (MSI) has been reported in gastric cancer and associated with older age of presentation, distal tumor location, early disease staging, and better overall prognosis. Different characteristics in presentation and in tumor behavior may be explained by different genetic alterations during carcinogenesis of gastric cancer. Identification of specific genetic pathways in gastric cancer may have direct impact on prognosis and selection of treatment strategies.

PATIENTS AND METHODS: All 24 patients were treated by radical surgery. Fragments of normal and tumor tissues were extracted from the specimen and stored at $-80^{\circ} \mathrm{C}$ before DNA purification and extraction. PCR amplification utilizing microsatellite markers was performed. Tumors presenting PCR products of abnormal sizes were considered positive for microsatellite instability (MSI+).

RESULTS: Five patients (21\%) had tumors that were MSI+ in at least 1 marker. In the group of patients with Lauren's intestinal-type gastric carcinoma, 3 had tumors that were MSI+ (23\%), while in the group of diffuse-type gastric cancer, 2 patients had tumors that were MSI+ (19\%). The mean age of presentation and the male:female ratio was similar in both groups. Tumors that were MSI+ were more frequently located in proximal portion of the stomach compared to microsatellitestable (MSS) tumors (40\% vs. 16\%). Although there was a trend of patients with MSI+ tumors towards a proximal gastric tumor location, early staging, and negative lymph node metastasis, there was no statistical significance compared to those with MSS tumors $(P>.1)$. Comparison of overall and disease-free survival between gastric tumors that were MSI+ and those that were MSS found no statistically significant differences $(P>.1)$.

CONCLUSIONS: Microsatellite instability is a frequent event in gastric carcinogenesis and shows a trend towards distinct clinical and pathological characteristics of gastric cancer.

KEY WORDS: Gastric cancer. Genetics. Microsatellite instability.

Gastric adenocarcinoma is one of the most common malignancies worldwide, but genetic steps involved in its carcinogenesis remain uncertain. Multiple genetic alterations affecting proto-oncogenes, tumor suppressor genes, and mismatch repair genes (MMR) appear to be associated with the development of various human cancers including colorectal and gastric cancers.
Identification of MMR genes, which are responsible for hereditary nonpolyposis colon cancer, led to the hypothesis of a distinct genetic pathway in colorectal cancer associated

From the Disciplines of Surgery of the Digestive Tract and Coloproctology, Hospital das Clínicas, Faculty of Medicine, University of São Paulo - São Paulo/SP, Brazil. E-mail: rcindy@uol.com.br Received for publication on January 29, 2004. with microsatellite instability (MSI) or replication error phenotype (RER) by alterations in 1 or more of these genes, more frequently in Msh2 and Mlh1. 17,7

Recently, the presence of MSI has also been reported in gastric cancer along with the association of these alterations with older age of presentation, distal tumor location, early disease staging, and better overall prognosis. ${ }^{5,10,13}$ Different characteristics in 
presentation and in tumor behavior may be explained by different genetic alterations during carcinogenesis of gastric cancer. Identification of specific genetic pathways in gastric cancer may have direct impact on prognosis and selection of treatment strategies.

We report in this prospective study involving 24 Brazilian patients with solitary and sporadic gastric cancer, the incidence of MSI, its correlation with epidemiological, clinical and pathological characteristics, and impact on overall and disease-free survival.

\section{PATIENTS AND METHODS}

Twenty-four patients with a preoperative diagnosis of gastric adenocarcinoma treated at Hospital das Clínicas, Faculty of Medicine, University of São Paulo (Department of Gastroenterology) and "Hospital Alemão Osvaldo Cruz" entered the study. All patients were treated by radical surgery including gastric resection with free margins and D2 lymphadenectomy according to the JSRGC anatomical classification. All patients were eligible for the study and had their resected specimens available for pathologic examination and MSI determination.

Tumors were characterized according to Lauren's histologic classification into intestinal - and diffuse-type gastric cancer and staged according to JGCA recomendations. ${ }^{19}$ The same surgeon and surgical team performed all operations.

Of the 24 patients, 15 were male $(62.5 \%)$ and 9 female $(37.5 \%)$. The mean age was 63.6 years (range, 26 to 86 years). Eleven patients (46\%) had Lauren's intestinal-type adenocarcinoma while 13 patients (54\%) had diffuse-type adenocarcinoma. Twelve patients (50\%) had tumors located in lower third of the stomach, 7 in the middle third (29\%), and 5 in the upper third (21\%). Total gastrectomy was performed in 11 patients
(46\%), and subtotal gastrectomy in the remaining 13 patients (54\%). Associated resection of the spleen was performed in 8 patients who were treated by total gastrectomy $(84.5 \%)$. Pathological examination revealed a mean number of lymph nodes resected of 33.6 (range, 17 to 76 ). Patient demographics are summarized in Table 1.

Nine patients (37.5\%) had T1 (mucosa and submucosa) tumors, 2 patients (8.3\%) had T2 (muscular layer), 12 patients $(50 \%)$ had T3 (serosal or subserosal), and $1(4.2 \%)$ had a $\mathrm{T} 4$ (adjacent organs). Nine patients (37.5\%) had no positive lymph nodes (N0), $9(37.5 \%)$ were classified as N1, and $6(25 \%)$ were classified as N2.

All patients had preoperative endoscopic biopsies of primary tumors. However, these preoperative studies did not include normal adjacent tissue biopsies for Helicobacter pylori infection determination. Since the surfaces of all resected specimens were washed with saline solution in order to avoid DNA contamination, determination of Helicobacter pylori infection would be seriously compromised and inaccu- rate in this setting. For this reason, pathologic examination of the resected specimen did not include $H$. pylori infection determination.

Only 1 patient (4.2\%) had a distant metastasis in the left ovary and was classified as stage IV. Eight patients (33.3\%) had stage I disease (stage Ia + Ib), 5 (21\%) had stage II, and 10 $(41.5 \%)$ had stage III (IIIa + IIIb) disease. Stage classification and patient distribution are summarized in Tables 2 and 3.

Table 1 - Patient Demographics (N=24).

\begin{tabular}{ll}
\hline Age & $26-86$ \\
Mean & 63.6 years \\
Gender & $15(62.5 \%)$ \\
$\quad$ Male & $9(37.5 \%)$ \\
Female & $13(54 \%)$ \\
Histologic type (Lauren) & \\
Intestinal & $11(46 \%)$ \\
$\quad$ Diffuse & \\
Tumor location & $12(50 \%)$ \\
L (distal third) & $7(29 \%)$ \\
M (intermediate) & $5(21 \%)$ \\
U (proximal third) & \\
Types of gastrectomy & $11(46 \%)$ \\
Total & $13(54 \%)$ \\
Subtotal & $(17-76)$ \\
Lymphadenectomy & $341 \mathrm{ymph}$ nodes \\
$\quad$ Mean &
\end{tabular}

Table 2 - Stage and histologic type (Lauren's classification) $(\mathrm{N}=24)$.

\begin{tabular}{lllll}
\hline (JGCA-1998) & & Intestinal & Diffuse & Total \\
\hline & Ia & $5(38.5 \%)$ & $1(9 \%)$ & $6(25 \%)$ \\
Ib & 0 & $2(18 \%)$ & $2(8 \%)$ \\
II & $4(30 \%)$ & $1(9 \%)$ & $5(21 \%)$ \\
IIIa & $1(8 \%)$ & $6(55 \%)$ & $7(29 \%)$ \\
IIIb & $2(15.5 \%)$ & $1(9 \%)$ & $3(13 \%)$ \\
IV & $1(8 \%)$ & 0 & $1(4 \%)$ \\
\hline (TNM) & & Intestinal & Diffuse & Total \\
\hline & $T$ & & & $9(37.5 \%)$ \\
& $\mathrm{T}_{1}$ & $5(38.5 \%)$ & $4(36 \%)$ & $2(8 \%)$ \\
$\mathrm{T}_{2}$ & $1(8 \%)$ & $1(9.5 \%)$ & $12(50 \%)$ \\
$\mathrm{T}_{3}$ & $7(54 \%)$ & $5(45 \%)$ & \\
& $\mathrm{T}_{4}$ & 0 & $1(9.5 \%)$ & $9(37.5 \%)$ \\
& & & & $9(37.5 \%)$ \\
& $N$ & $8(61.5 \%)$ & $1(9 \%)$ & $6(25 \%)$ \\
$\mathrm{N}_{0}$ & $2(15.5 \%)$ & $7(63 \%)$ & $23(96 \%)$ \\
$\mathrm{N}_{1}$ & $3(23 \%)$ & $3(27 \%)$ & $1(4 \%)$ \\
& $\mathrm{N}_{2}$ & & & $24(100 \%)$ \\
& $M$ & & $11(100 \%)$ &
\end{tabular}


Table 3 - Japanese Gastric Cancer Association Staging System-1998 ${ }^{19}$.

\begin{tabular}{lccc}
\hline & \multicolumn{3}{c}{ Staging JGCA } \\
Stage & T & N & M \\
\hline IA & T1 & N0 & M0 \\
IB & T1 & N1 & M0 \\
& T2 & N0 & M0 \\
II & T1 & N2 & M0 \\
& T2 & N1 & M0 \\
& T3 & N0 & M0 \\
IIIA & T2 & N2 & M0 \\
& T3 & N1 & M0 \\
& T4 & N0 & M0 \\
IIIB & T3 & N2 & M0 \\
& T4 & N1 & M0 \\
IV & T4 & N2 & M0 \\
& Any T & N3 & Any M \\
& Any T & Any N & M1 \\
\hline
\end{tabular}

\section{Tissue and DNA preparation}

Fragments of normal and tumor tissues were extracted from the specimen immediately after resection. The specimen surface was washed with saline fluid prior to fragment extraction to avoid DNA contamination of tissues sent for MSI determination. Areas of tissue extraction from the specimen were demarcated for routine pathologic examination. Only tissue fragments containing adenocarcinoma were included for MSI analysis. Normal areas were used as controls. Tissues were stored at $-80^{\circ} \mathrm{C}$ before DNA purification and extraction.

Tissues were incubated overnight at $55^{\circ} \mathrm{C}$ in a buffer containing $100 \mathrm{mM}$ TRIS-HCl (pH 8.5), 5 mM EDTA, 200 $\mu \mathrm{g}$ of proteinase $\mathrm{K} / \mathrm{mL}$, and $0.2 \%$ sodium dodecyl sulfate. The samples were cooled to room temperature, and DNA was precipitated with isopropanol and dissolved in $500 \mathrm{~mL}$ of buffer containing $10 \mathrm{mM}$ TRIS (pH 8.2) and 1 mM EDTA. ${ }^{1}$

\section{Microsatellite markers and PCR am- plification}

Oligonucleotide primers for microsatellite markers from the long arm of chromosome 18 were designed on the basis of published sequences (D18S55, D18S58, D18S61, D18S64, and D18S69) ${ }^{8}$. PCR-based dinucleotide repeat assays were carried out in 96-well plates for 30 cycles; each cycle was carried out at $95^{\circ} \mathrm{C}$ for 30 seconds, $50^{\circ} \mathrm{C}$ for 1 minute, and $70^{\circ} \mathrm{C}$ for 1 minute. Two volumes of stop buffer ( $95 \%$ of formamide, $20 \mathrm{uM}$ sodium hydroxide, and $0.05 \%$ bromophenol blue and xylene cyanate) were added at the end of the amplification, plates were boiled in a water bath for 10 minutes at $100^{\circ} \mathrm{C}$, and the samples were loaded onto $7 \%$ polyacrylamide gels containing $32 \%$ formamide and 5.6 $\mathrm{M}$ urea. ${ }^{4}$

\section{Determination of microsatellite in- stability (MSI)}

Tumors presenting PCR products of abnormal sizes were considered positive for MSI (MSI+). Tumors that were MSI+ for 1 marker were considered low-MSI, and tumors that were MSI+ for 2 or more markers were considered high-MSI. Detection of PCR products was made by Sybr-Green staining of the polyacrylamide gels.

\section{Statistical analysis}

Statistical analysis was performed using the Student $t$ test and chi-square test. Overall survival and disease-free Kaplan-Meier curves were compared using the log-rank test.

\section{RESULTS}

Five patients (21\%) had tumors that were MSI+ in at least 1 marker (MSI+ group), and 19 patients (79\%) had tumors that were microsatellite-stable (MSS) (MSS group). Of the patients having tumors that were MSI+ 3 $(12.5 \%)$ were considered high-MSI, and $2(8.3 \%)$ were considered low-MSI.

In the group of patients with Lauren's intestinal-type gastric carci- noma, $3(23 \%)$ had tumors that were MSI+, while in the group of diffusetype gastric cancer, 2 patients (19\%) were MSI+. These differences were not statistically significant $(P=.58)$.

In the MSI+ group, the mean age was 63.6 years and the male:female ratio was 1.5 ; in the MSS group, the mean age was also 63.6 and the male:female ratio was 1.75 . Tumor location in patients having MSI+ tumors was $1(20 \%)$ in the distal third, $2(40 \%)$ in the middle third, and $2(40 \%)$ in the upper third of the stomach. In the MSS group, 11 patients $(58 \%)$ had tumors in the lower third, 5 (26\%) in the middle, and $3(16 \%)$ in the upper third of the stomach. Three patients in the MSI+ group $(60 \%)$ and 5 patients in the MSS group (26\%) had Stage I disease. Lymph node metastasis was present in 1 patient in the MSI+ group (20\%) and in 14 patients in the MSS group (74\%). There were no statistically significant differences between groups in terms of age and gender distribution $(P=.9$ and $P=$ .6 , respectively). Although there was a trend for patients in MSI+ group towards proximal tumor location, early staging, and negative lymph node metastasis, there was no statistical significance, $P>$.1. (Table 4)

In the group of patients with Lauren's intestinal-type gastric carcinoma, the mean overall survival was 33.6 months for patients with MSI+ tumors and 33.1 months for patients with MSS tumors. In this subgroup, none of the patients with MSI+ tumors had recurrence of the disease, while 2 patients with MSS tumors (20\%) had systemic recurrent disease. In this group of patients, when patients with MSI+ and MSS tumors are compared within stages, mean overall survival and disease recurrence rates are identical.

In the group of patients with Lauren's diffuse-type gastric carcinoma, mean overall survival was 45.5 months for patients with tumors that were MSI+ and 30.9 months for pa- 
Table 4 - Clinicopathological differences between microsatellite instability (MSI+) and microsatellite-stable (MSS).

\begin{tabular}{lccc}
\hline & MSI+ & MSS & $P$ \\
\hline $\mathrm{N} \quad$ & 05 & 19 & \\
\hline Age (mean) & 63.3 & 63.6 & .9 \\
Gender (M:F) & 1.5 & 1.75 & .6 \\
Tumor location & $1(20 \%)$ & $11(58 \%)$ & .24 \\
$\quad \mathrm{~L}$ & $2(40 \%)$ & $5(26 \%)$ & \\
$\mathrm{M}$ & $2(40 \%)$ & $3(16 \%)$ & \\
$\quad \mathrm{U}$ & $3(60 \%)$ & $8(42 \%)$ & .76 \\
Operation (type of gastrectomy) & $2(40 \%)$ & $11(58 \%)$ & \\
$\quad$ Total & $3(60 \%)$ & $10(52 \%)$ & .58 \\
$\quad$ Subtotal & $2(40 \%)$ & $9(48 \%)$ & \\
Histologic type (Lauren) & $3(60 \%)$ & $5(26 \%)$ & .48 \\
$\quad$ Intestinal & $2(40 \%)$ & $14(74 \%)$ & \\
$\quad$ Diffuse & & & \\
Stage & $4(80 \%)$ & $5(26 \%)$ & .54 \\
$\quad$ Early (stage I) & Advanced (II-IV) & &
\end{tabular}

tients with tumors that were MSS. In this subgroup, none of the patients with MSI+ tumors had recurrence of the disease, while 3 patients with MSS tumors $(20 \%)$ had systemic recurrent disease. These differences were not statistically significant. In patients with Lauren's diffuse-type gastric cancer, the difference between mean overall survival and disease-free survival was seen only in the stage III subgroup of patients, where the mean survival time of patients with MSI+ tumors was 54 months with no recurrence and for patients with MSS tumors was 31.5 months with 1 recurrence (25\%). (Figs. 1 and 2). However, the small number of patients in this subgroup (stage III) may account for such differences.

\section{DISCUSSION}

We found microsatellite instability (MSI) in $21 \%$ of 24 sporadic and solitary gastric adenocarcinomas in Brazilian patients, which is in accordance with other reports in the literature, which cite incidences of $9 \%$ to $33 \% .^{10,13,8,16,2,18,6}$ Furthermore, we also found similar results concerning the frequent early disease staging encoun-
MSI+ tumors in our study were more frequently located in the proximal third $(40 \%)$ of the stomach when compared to MSS tumors (16\%). Also, mean age was identical between both groups at 63.6 years.

We compared overall and diseasefree survival between patients with MSI+ and MSS gastric tumors and found no statistically significant differences. These results also differ from earlier reports in the literature. ${ }^{13,16,2,18,6}$

The presence of the replication error (RER) phenotype in gastric cancer appears to represent an independent genetic pathway in gastric carcinogenesis. ${ }^{9,12,15}$ The incidence of this phenotype has been reported to be even higher $(50 \%)$ in multiple or synchronic gastric tumors. ${ }^{9}$ A recent study has shown that tumors that exhibit RER rarely exhibit loss of heterozygosity, considered to be the other major genetic pathway in gastric carcinogenesis. ${ }^{12,11}$ Additionally, multiple tumors in the same stomach usually present the same phenotype more frequently with MSI. ${ }^{12}$ These synchronic or multiple gastric tumors may be further divided in 2 subgroups, the first when there is an adenoma-associated adenocarcinoma (type I) and the second when there is no adenoma associated

(type II). These authors report an im-

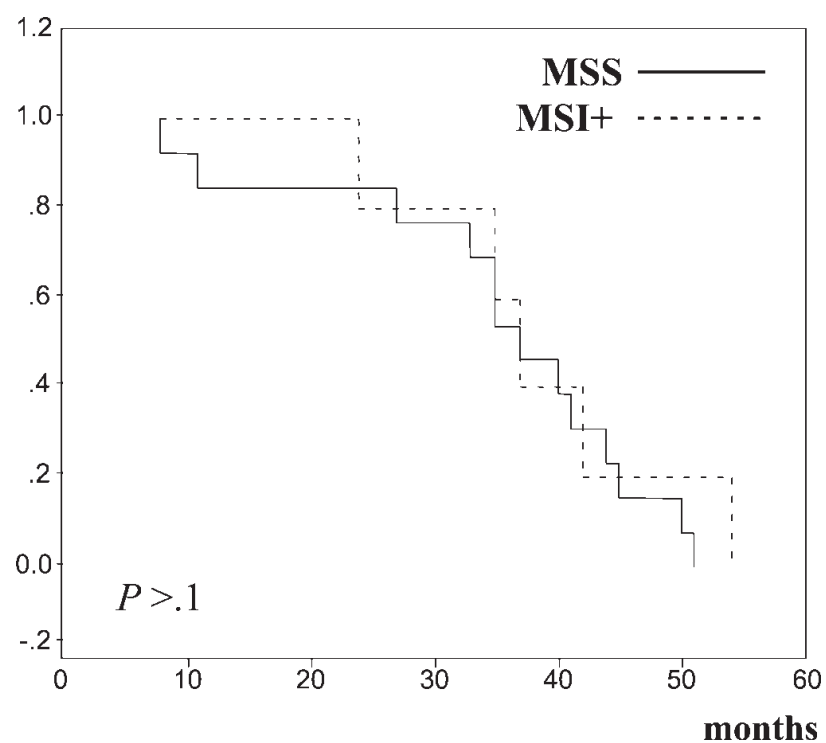

Figure 1 - Overall survival of patients with gastric cancer according to microsatellite instability (MSI) status. 


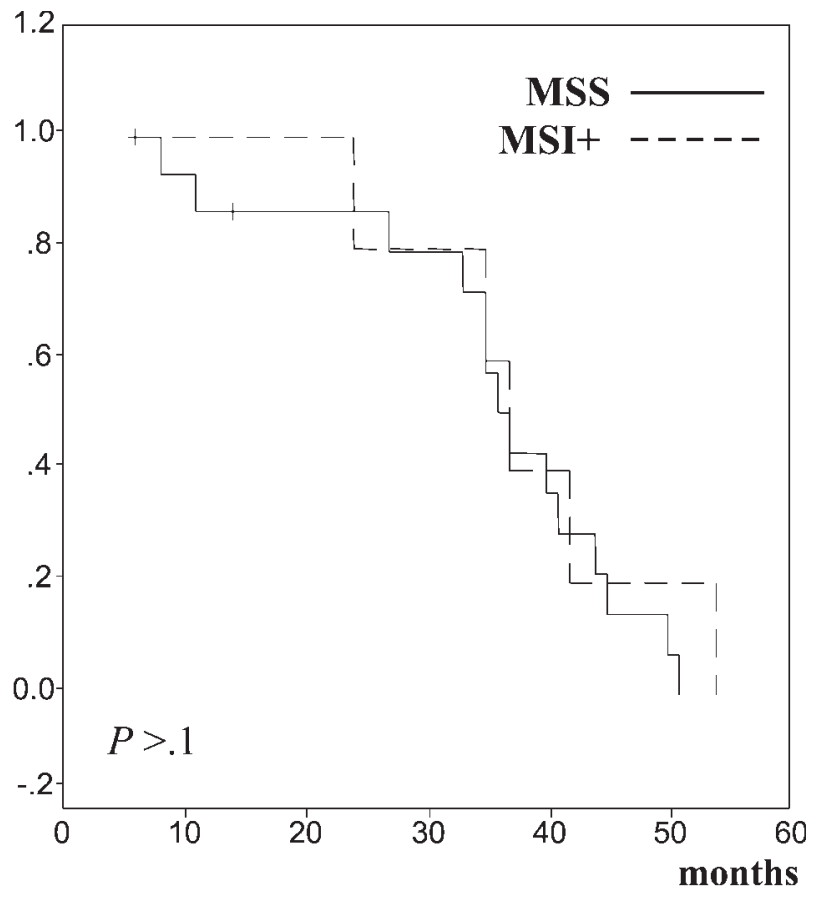

Figure 2 - Disease-free survival according to microsatellite instability (MSI) status.

portant difference in the incidence of MSI between these subgroups, being more frequent in type I (56\%) and infrequent in type II (8\%). ${ }^{9}$ The presence of MSI may be associated with mutations in specific target genes such as TGFb RII, IGFII R, and BAX. ${ }^{13,9}$ The combination of mutation in target genes may be responsible for differences in biological behavior and clinical-pathological characteristics within MSI+ tumors.

Association of genetic alterations and dietary factors have also been studied. Recently, an Italian study has suggested a correlation between red meat ingestion and MSI+ gastric cancer, suggesting an environmental factor as a causative event in susceptible individuals or increased tolerance to DNA damage associated with reduced MMR activity. ${ }^{14}$

MLH1 and MSH2 appear to be responsible for the majority of the MSI both in colorectal cancer and gastric cancer. ${ }^{3,4}$ The mechanism involved more frequently is hypermethylation of the MLH1 promoter region resulting in underexpression of the protein as ob- served by immunohistochemistry. $3,4,1$ Recent observations have indicated that even adjacent noncancerous tissue may present hypermethylation of MLH1 promoter region and may be associated with increased risk for the development of gastric cancer. ${ }^{15,1}$

These results suggest that MSI may be an important and early event in a subset of gastric adenocarcinomas. In our study, although not statistically significant, MSI+ tumors showed a trend towards early disease staging, proximal gastric location, and lower risk for lymph node metastasis. Furthermore, we found no difference in the mean age of these patients, overall survival, and disease-free survival, in contrast with observations of others. ${ }^{13,16,2,18,6}$ We believe that tumor aggressiveness and biological behavior may be determined by target gene mutations and thus these should be identified in order to compare different subsets of gastric tumors all exhibiting the RER or MSI+ phenotype. Furthermore, MSI+ gastric cancer may be the end-result of environmental or dietary factors in a susceptible stomach. These two arguments may account for the clinical-pathologic and survival differences observed in our study.

Identification of genetic pathways in gastric cancer may be of great importance and have direct practical implications in the management of gastric cancer. Tumor biological behavior may be directly associated with specific genetic alterations during carcinogenesis of gastric cancer. These differences may account for the heterogeneity of presentation and prognosis of this neoplasm. Thus, patients may have a distinct prognosis, presentation characteristics, and response to therapy according to specific genetic alterations and pathway.

Treatment of gastric cancer is based on radical surgical resection. Extent of gastric resection is determined by tumor histology and location. Some genetic alterations, such as MSI and mutations in MMR genes, may be associated with increased risk of multiple synchronous tumors and therefore may require total gastrectomy as an initial treatment strategy, once it can be diagnosed preoperatively. An environmental factor may also influence these aspects, since dietary factors and specific carcinogenic agents may influence in a variable manner the manifestation in a common genetic background. Our results differ from other reports in several aspects of tumor presentation and behavior of MSI+ gastric tumors, which may be partially explained by a different environmental factor not yet identified.

Hereditary genetic alterations may be responsible for increased susceptibility for cancer. Detection of these genetic changes may allow identification of relatives of patients with gastric cancer with increased risk for development of the disease, such as hereditary diffuse and intestinal gastric cancer. Distinct screening programs for these families may lead to higher rates of 
early gastric cancer diagnosis, improve overall survival, and revive the discussion about prophylactic treatment of gastric cancer.

Adjuvant therapy has not yet shown consistent improvement in overall survival for gastric cancer. Characterization of specific genetic alterations and pathways may allow identification of a subset of patients with gastric cancer that is susceptible to specific antineoplastic drugs. Furthermore, neoadjuvant treatment with chemotherapy and radiotherapy may prove to be beneficial in selected cases of advanced or even unresectable disease. Alterations in specific genes such as p53 and other genes associated with apoptosis may be responsible for some of these differences observed in adjuvant treatment responses. In theory, a genetic pathway that does not include frequent alterations in such genes may be associated with better response to chemotherapy and radiotherapy with adjuvant or neoadjuvant intent. As mentioned earlier, MSI may represent a distinct genetic pathway of gastric cancer and does not include frequent alterations in p53 gene and others. One could expect better response rates with specific chemotherapeutic regimens for adjuvant treatment in MSI+ tumors.

Finally, identification of these specific genetic alterations and pathways may aid in the development of new drugs involving gene therapy, such as viral vectors directed to specific target genes causing tumor cell death with minimum toxicity.

The importance of the study of genetic alterations in gastric cancer development cannot be overemphasized, but new management strategies based on these characteristics should await further consistent results. Caution should be taken with interpretation of these re- sults with special consideration to different geographical areas and other environmental factors. These factors may be responsible for different influences in gastric carcinogenesis, giving rise to tumors with distinct biological behaviors and presentation over similar genetic alterations or pathways.

In conclusion, MSI is a frequent event in gastric carcinogenesis and can be easily detected. The presence of MSI may be associated with distinct clinical, epidemiological, and pathological characteristics, such as primary tumor location, disease stage, and presence of lymph node metastases. Different geographical areas and environmental factors may further influence the association between MSI and these features in gastric cancer. Identification of genetic and molecular events in gastric carcinogenesis may result in improvement of disease management and overall survival.

\section{RESUMO}

Perez RO e col. Instabilidade de microsatelites no cancer gástrico solitário e esporádico. Rev. Hosp. Clín. Fac. Med. S. Paulo 59(5): 279-285, 2004.

A presença de Instabilidade de microsatellites (IMS) tem sido relatada no cancer gastrico e associada a pacientes com idade mais avançada, localização mais distal do tumor, estadios mais precoces e melhor prognostico. Relatamos neste prospectivo estudo envolvendo 24 pacientes com cancer gastrico solitario e esporadico, a incidencia de IMS, sua correlação com parametros epidemiologicos, clinicos e anatomo patológicos e o seu impacto sobre a sobrevida geral e livre de doença.
PACIENTES E MÉTODOS: Todos os pacientes haviam sido tratados com cirurgia radical. Fragmentos de tecido normal e tumoral eram extraidos das peças e armazenados a $80^{\circ} \mathrm{C}$ antes da extração e purificação DNA. Realizava-se então a amplificação com PCR utilizando marcadores específicos de microsatelites. Os tumores que apresentavam produtos de amplificação anormais foram considerados positivos para IMS.

RESULTADOS: Cinco pacientes $(21 \%)$ apresentaram Instabilidade de microsatelites (IMS+) com pelo menos um marcador (primer) No grupo de pacientes com adenocarcinomas gástricos do tipo histológico de Lauren, três apresentavam IMS (23\%) enquanto no grupo portador de cancar gástrico difuso, dois pacientes mostraram IMS (19\%).. Embora haja uma tendência dos pacientes IMS+ apresentarem tumores de localização mais proximal, estadios mais precoces e ausência de metástases linfonodais, não se observou diferenças estatisticamente significativas $(p>0,1)$. A comparação entre as taxas de sobrevida geral e livre de doença não mostrou significância estatistica ( $\mathrm{p}>0,1)$.

CONCLUSÕES: IMS é um evento frequente na carcinogese gástrica e pode estar associado a caracteristicas clinicas e anátomo-patológicas do câncer gástrico.

UNITERMOS: Câncer gástrico. Genética. Instabilidade de microsatelites. 


\section{REFERENCES}

1. Baek MJ, Kang H, Kim SE, Park JH, Lee JS, Paik YK, Kim H. Expression of hMLH1 is inactivated in the gastric adenomas with enhanced microsatellite instability. $\mathrm{Br} \mathrm{J}$ Cancer 2001;85:1147-52.

2. Chung YJ, Park SW, Song JM, Lee KY, Seo EJ, Choi SW, et al. Evidence of genetic progression in human gastric carcinomas with microsatellite instability. Oncogene 1997;15:1719-26.

3. Cunningham JM, Christensen ER, Tester DJ, Kim CY, Roche PC, Burgart LJ, et al. Hypermethylation of the hMLH1 promoter in colon cancer with microsatellite instability. Cancer Res 1998;58:3455-60.

4. Fleisher AS, Esteller M, Wang S, Tamura G, Suzuki H, Yin J, et al. Hypermethylation of the hMLH1 promoter in human gastric cancer with microsatellite instability. Cancer Res 1999;59:10905 .

5. Han HJ, Yanagisawa A, Kato Y, Park JG, Nakamura Y. Genetic instability in pancreatic cancer and poorly differentiated type of gastric cancer. Cancer Res 1993;53:5087-9.

6. Hayden JD, Cawkwell 1, Quirke P, Dixon MF, Goldstone AR, SueLing $\mathrm{H}$, et al. Prognostic significance of microsatellite instability in patients with gastric carcinoma. Eur J Cancer 1997;33:23426.

7. Ionov Y, Peinado MA, Malkhosyan S, Shibata D, Perucho M. Ubiquitous somatic mutations in simple repeated sequences reveals a new mechanism for colonic carcinogenesis. Nature 1993;363:558-61.

8. Jen J, Kim H, Piantadosi S, Liu ZF, Levitt RC, Sistonen P, et al. Allelic loss of chromosome 18q and prognosis in colorectal cancer. N Engl J Med 1994);331(4):213-21.

9. Lee HS, Lee BL, Kim SH, Woo DK, Kim HS, Kim WH. Microsatellite instability in synchronous gastric carcinomas. Int J Cancer 2001);91:619-24.

10. Nakashima $\mathrm{H}$, Inoue $\mathrm{H}$, Mori $\mathrm{M}$, Ueo $\mathrm{H}$, Ikeda $\mathrm{M}$, Akiyoshi $\mathrm{T}$. Microsatellite instability in Japanese gastric cancer. Cancer 1995;75(3)supp:1503-7.
11. Nishizuka S, Tamura G, Terashima M, Satodate R. Loss of heterozygosity during the development and progression of differentiated adenocarcinoma of the stomach. J Pathol 1998);185:38-43

12. Ogata S, Tamura G, Endoh Y, Sakata K, Ohmura K, Motoyama T. Microsatellite alterations and target gene mutations in the early stages of multiple gastric cancer. J Pathol 2001;194:334-40.

13. Oliveira C, Seruca R, Sobrinho-Simões M, Seixas M. The clinicopathological features of gastric carcinoma with microsatellite instability may be mediated by mutations of different "target genes". Am J Pathol 1998;153(4):1211-9.

14. Palli D, Russo A, Ottini L, Masala G, Saieva C, Amorosi A, et al. Red meat, family history, and increased risk of gastric cancer with of gastric cancer with microsatellite instability. Cancer Res 2001;61:5415-9.

15. Sakata K, Tamura G, En Y, Ohmura K, Ogata S, Motoyama T. Hypermethylation of the hMLH1 gene promoter in solitary and multiple gastric cancers with microsatellite instability. Br J Cancer 2002;86:564-67.

16. Seruca R, Santos NR, David L, Constancia M, Barroca H, Carneiro F, et al. Sporadic gastric carcinomas with microsatellite instability display a particular clinicopathologic profile. Int J Cancer 1995;64:32-6.

17. Thibodeau SN, Bren G, Schaid D. Microsatellite instability in cancer of the proximal colon. Science 1993;260:816-9.

18. Wu MS, Lee CW, Shunt CT, Wang HP, Lee WJ, Sheu JC, Lin JT Clinico-pathological significance of altered loci of replication error and microsatellite instability-associated mutations in gastric cancer. Cancer Res 1998;58:1494-7.

19. Nakajima T. Gastric câncer treatment guidelines in Japan. Gastric Câncer 5: p1-5, 2002 